\title{
Effect on Yield and Quality of a Simple System to Recycle Nutrient Solution to Greenhouse Tomato
}

\author{
Martin P.N. Gent ${ }^{1}$ and Michael R. Short \\ Department of Forestry and Horticulture, Connecticut Agricultural \\ Experiment Station, P.O. Box 1106, New Haven, CT 06504
}

Additional index words. fertilizer, fruit quality, Solanum lycopersicon, tissue composition, water use

\begin{abstract}
Recycling the nutrient solution used for greenhouse vegetable production can prevent groundwater pollution. Recycling could result in an accumulation or deficiency of elements that would be deleterious to plant growth, product quality, and the dietary value of vegetables. Complex fertilizer systems have been developed to maintain appropriate concentrations of all elements in recycled systems. We compared a much simpler system in which all excess solution drained from the plants was recycled without adjustment or dilution compared with a system with no recycling as a control. Crops of greenhouse tomato (Solanum lycopersicon $\mathrm{L}$.) were grown in two years to compare these systems. Differences in composition of solution drained from the plants developed gradually over more than one month. The transition from vegetative to fruit growth, which coincided with warmer weather, resulted in a decreased demand for nitrate, and other nutrients, and an increase in electrical conductivity (EC) of water drained from the root zone. The composition of the fresh solution supplied to the plants was adjusted accordingly. It took a longer time to re-establish an optimum composition for recycled compared with control watering. EC tended to increase in the recycled system. Recycling decreased total yield and fruit size, but marketable yield was unaffected. The marketable fraction increased in the recycled treatment, primarily as a result of fewer fruit with cracked skin. This effect was consistent across seven cultivars. The cultivars differed in this and other defects, but they did not differ in their response to the two watering systems.
\end{abstract}

Reuse of solution after it has once been used to water plants can prevent groundwater pollution from the use of fertilizer in intensive agricultural production. The smaller the volume of nutrient solution discarded, the less likelihood of excess nutrients contaminating the land or groundwater. The Netherlands (Anonymous, 1989) specifies that greenhouse growers may not discharge wastewater, because of concern regarding surface and groundwater pollution with nutrients and pesticides. In the future, regulations similar to these may be imposed in the United States. Growers that produce on a large scale, 4 ha or more, have incorporated increasingly sophisticated nutrient supply systems to maintain the concentration of all elements within narrow limits and to prevent spread of disease when the water is recycled (van Os et al., 2008). Small-scale growers, less than 0.1 ha in production, are the dominant sector in New England. These growers cannot afford either a complex irrigation system or the continuous chemical assays needed to determine whether the nutrients need adjustment resulting from environment or plant growth. They use a simple irrigation system with a solution of pre-

Received for publication 9 July 2012. Accepted for publication 11 Sept. 2012.

${ }^{1}$ To whom reprint requests should be addressed; e-mail Martin.Gent@ct.gov. mixed and diluted fertilizer that is delivered at timed intervals or according to the grower's schedule, or one or more nutrient concentrates are diluted into the water at the time it is delivered to the plants. The affordable measurements are $\mathrm{pH}$ and EC. Is a simple system for recycling nutrients viable using these relatively simple tools? A first step to introduce recycling to such a simple growing system is to collect the drained solution in a reservoir and return it to the plants in a secondary water cycle. Is such a procedure applicable in a commercial setting? What precautions are required to prevent an excess or depletion of specific nutrients in the solution?

Many factors affect the EC and concentrations of nutrients in water drained from plants. These include environmental conditions, plant growth and development, and the volume and concentration of nutrient solution supplied. Environment has an effect on transpiration rate and water uptake through radiation and air temperature (Norrie et al., 1994). Nitrogen use may change with radiation integral (Charbonneau et al., 1988). The ratio of nitrogen to potassium taken up by tomato plants changes from vegetative to reproductive growth (Resh, 1991; Wittwer and Honma, 1979). A slight imbalance between the supply and uptake of a nutrient by the plant could result in a large change in concentration in the root zone. Knowledge of nutrient requirements is needed to prevent overfertilization or depletion. Can this be done by monitoring only EC and nitrate? Such a protocol could be used by small growers that cannot afford a more complete set of measurements.

An imbalance in concentrations of potassium, calcium, and magnesium can have deleterious consequences to plant growth, product quality, and the dietary value of vegetables (Roorda van Eysinga and Smilde, 1981). The buffering capacity of the root medium has an effect on nutrient concentrations when solutions are recycled. When tomato was grown for 12 weeks with recycled solution, sulfate accumulated 2 -fold more and yield was depressed with recycling using nutrient film compared with recycling using rockwool or peat media (Zekki et al., 1996). Reuse of nutrient solutions, or of groundwater leached from agricultural lands, tends to increase salinity (Grattan and Grieve, 1999). This occurs because plants partially exclude those ions that are not needed for plant growth (Carmassi et al., 2005). When the concentration of these ions becomes sufficiently high in the root medium, they accumulate in plant tissues, and toxic symptoms develop. However, water quality, specifically high salinity, is not a factor in the eastern United States, where rainfall is generally greatly in excess of evapotranspiration.

A solution with high EC resulting from ions other than sodium also affects the uptake of essential nutrients. Increasing nutrient concentrations and EC from 2 to $6 \mathrm{dS} \cdot \mathrm{m}^{-1}$ had little effect on nitrogen or potassium levels in tomato leaves, but it lowered calcium (Charbonneau et al., 1988). Sulfate could combine with calcium in solution, forming $\mathrm{CaSO}_{4}$, thus rendering the calcium unavailable to the plant (Lopez et al., 2003). Calcium deficiency is a known cause of blossom-end rot in tomato (Ho et al., 1995).

Coconut coir has been found to be a suitable substrate for greenhouse tomato production. Many studies have noted equal or greater yield in coir than conventional root media (Jensen et al., 2004; Kobryn, 2002; Mazuela et al., 2004; Rincon et al., 2005). Compared with rockwool, coir has a higher cation exchange capacity that helps minimize the increase in nutrient concentrations that occurs with recycling (Iwasaki and Saigusa, 2001).

We grew greenhouse tomato in coir substrate with or without recycling to see what changes in the composition of the nutrients occur under this scenario. A system in which the excess solution drained from the plants was recycled through a secondary watering system each week was compared with a control in which only fresh nutrient solution was supplied to the plants. Otherwise the watering system was similar to that used by small growers with complete nutrient solutions supplied at a fixed concentration with infrequent adjustments over time. Adjustments were made to watering volume, based on the volume drained, and to the nutrient concentration, based on the EC of the drained 
solution. We report the results from the seven cultivars that were grown in each of these watering systems in two years.

\section{Materials and Methods}

Growth conditions. The experiment was conducted in Hamden, CT (lat. $42^{\circ} \mathrm{N}$, long. $73^{\circ} \mathrm{W}, 50 \mathrm{~m} \mathrm{ASL}$ ) in two hoophouses, $17.1 \mathrm{~m}$ long $\times 4.3 \mathrm{~m}$ wide $\times 2.7 \mathrm{~m}$ high, with a double glazing of $0.1-\mathrm{mm}$ clear polyethylene film. Greenhouses were heated to a minimum temperature of $14{ }^{\circ} \mathrm{C}$ until June. The ventilation temperature was $28^{\circ} \mathrm{C}$. After 15 June, the sides of the greenhouse were rolled up to provide continuous ventilation. Seeds were germinated under controlled conditions on 28 Jan. in 2008 and 2009, and seedlings were transplanted into the greenhouses on 13 and 12 Mar. in 2008 and 2009. Seven cultivars of greenhouse tomato (Solanum lycopersicon L.) were grown in both years. The cultivars and seed sources were: Arabason, Buffalo, and Trust (Johnny's Select Seed, Winslow, ME); Blitz and Geronimo (DeRuiter Seeds, Bergschenhoek, The Netherlands); Cobra (Stokes Seeds, Buffalo, NY); and Rapsodie (Hydrogardens, Colorado Springs, CO). Six plants in a row corresponded to one subplot of each cultivar. Three plants were set into each $100 \times 15 \times 12-\mathrm{cm}$ grow-bag of coir (washed, dried, and compressed coconut coir enclosed in white on black poly; Fiber Dust LLC, Glastonbury, $\mathrm{CT}$ ). Shoots were spaced $0.6 \mathrm{~m}$ apart in rows spaced $0.9 \mathrm{~m}$ apart, giving a density of 1.8 plants $/ \mathrm{m}^{2}$. Rows ran east-west along the length of each house, and shadecloth reduced sunlight intensity on the south row by $50 \%$ to correspond to the shade effect by other rows. Plants were supported by string and pruned to a single stem. Trusses were pruned to four or five fruit. Leaves were pruned to below the truss with ripe fruit.

Supply of water and nutrients. Water was supplied to the plants by a pressurized system through precision drip emitters (PC-CNL 8.5 $\mathrm{L} \cdot \mathrm{h}^{-1}$; Netafim, Tel Aviv, Israel). The number of waterings varied from one to eight times per day, depending on the sunlight integral. The rate of supply per plant was $35 \mathrm{~mL} \cdot \mathrm{min}^{-1}$. The duration of watering was adjusted from 2 to 14 min according to plant size. Fresh nutrient solution was made with three concentrates: a complete nutrient fertilizer, $5 \mathrm{~N}-7.8 \mathrm{P}-31.6 \mathrm{~K}$ (Tomato formula; Hydrogardens), $\mathrm{Ca}\left(\mathrm{NO}_{3}\right)_{2}$, and $\mathrm{MgSO}_{4} \cdot 7 \mathrm{H}_{2} \mathrm{O}$. These fertilizers were mixed into the water supply using proportioners (A12 Advantage; Dosmatic, Carrollton, TX). Nitrogen was supplied at $200 \mathrm{mg} \cdot \mathrm{L}^{-1}$ during vegetative and early fruit growth. This concentration was reduced to $120 \mathrm{mg} \cdot \mathrm{L}^{-1}$ during fruit production by 13 June 2008 and 9 June 2009 . Potassium was supplied at $140 \mathrm{mg} \cdot \mathrm{L}^{-1}$ initially, and it was increased to $215 \mathrm{mg} \cdot \mathrm{L}^{-1}$ during fruit production. Phosphoric acid was used to control $\mathrm{pH}$. Clean water was used in some watering cycles to lower EC.

The solutions were drained into a black on white polyethylene film tube that enclosed the root medium of an entire row of plants. The drained solution was directed to one of two covered reservoirs and collected for one week. Then the solution in each reservoir was either recycled to the plants or discarded. Water was recycled by a magnetic drive pump (Model SM1212-26; Liang, Chula Vista, CA) that propelled water through a string-core filter and into a manifold of black polyethylene tubing that distributed water to each plant in the recycle treatment. Water was withheld from plants in the recycle treatment for $12 \mathrm{~h}$ before a recycle event so that most of the recycled solution would be retained in the root medium. Water in the control reservoir was pumped out of the greenhouse using a submersible pump.

Sampling and chemical analysis. Ripe fruit were picked at 4- to 5-d intervals. At each harvest, fruit from six plants per subplot were combined for counting, enumerated for defects, and weighed. Total yield, marketable yield, weight per fruit, and nature of defects of the fruit were recorded. Defects included radial and circular cracks in the skin, rough skin, green shoulder or uneven ripening, blossom-end rot, and cat-facing or irregular shape.

Every 1 or $2 \mathrm{~d}$, the $\mathrm{pH}$ and $\mathrm{EC}$ of the solutions drained from the plants were measured with a meter (HI 9813-0; Hanna Instruments, Woonsocket, RI). Samples were taken every 2 weeks for a more complete analysis of composition. The concentrations of nitrate and potassium were determined using selective electrodes (934601 and 931901; Thermo Fisher Scientific, Waltham, MA). Solution samples were diluted 2:1 with $8 \% \mathrm{w} / \mathrm{v} \mathrm{H}_{2} \mathrm{SO}_{4}$, and the concentrations of mineral elements were determined by inductively coupled plasma atomic emission (ICP) spectrometry (Atom Scan 16; Thermo-Jarrell Ash, Franklin, MA).

During one fruit harvest in July 2008 and another in 2009, two ripe fruit were selected from each subplot. These fruit were homogenized and dry matter was determined in two 10 -mL subsamples of each fruit sample. The dried material was digested in $4 \mathrm{~mL} \mathrm{H}_{2} \mathrm{SO}_{4}$ and $10 \mathrm{~mL} 30 \mathrm{w} / \mathrm{v} \% \mathrm{H}_{2} \mathrm{O}_{2}$ heated to boiling, then diluted to $100 \mathrm{~mL}$, and elemental composition determined by ICP spectrometry.

Experimental design and analysis. The experimental design was a split-split plot with two greenhouses as replicate plots and two watering systems within the greenhouse as the treatment subplots. There were four rows of plants, two for each watering system. Blocks of six plants of one cultivar were subplots within rows. There were four such blocks in each row and a total of eight different cultivars in the two rows for each treatment in each house. Position of cultivar was randomized within blocks, and treatment rows were different in each greenhouse. The entire experiment was repeated in two years.

Analysis of variance of yield components was conducted over both years. Effects of year, recycling, and cultivar within recycling and interactions between these effects were included in a general linear model in SYSTAT
(SPSS Version 10, Richmond, CA). Analysis of tissue or solution composition used the variation between replicates for each treatment as the source of error to determine the least significant difference at $P<0.05$.

\section{Results and Discussion}

Nutrient solution composition. The pattern of water use was similar in the two years of this study. Figure 1 shows the volume of fresh solution supplied per day to the plants and the volumes drained per plant. There was a rapid rise in water used as the plants grew vegetatively until early May. This rise was slightly delayed in 2009 compared with 2008. Then there was a more gradual rise to a maximum in water use of $\approx 3 \mathrm{~L} /$ plant (or $5.4 \mathrm{~mm} \cdot \mathrm{d}^{-1}$ when expressed as a volume per unit area of greenhouse) after one month of fruit production and then a gradual decline as the season was extended into September. The volume of water drained varied from day to day, because the supply was adjusted based on the amount drained, and the delay in feedback led to periods of low drainage followed by periods of high drainage. Drainage averaged less than $0.5 \mathrm{~L} /$ plant/d $\left(0.9 \mathrm{~mm} \cdot \mathrm{d}^{-1}\right)$. Over the entire season, irrigation supplied a total of 375 and $337 \mathrm{~mm}$ in 2008 and 2009, respectively. The volume drained from the control treatment was 64 and $59 \mathrm{~mm}$. Thus, the recycle treatment saved $17 \%$ and $14 \%$ of the water used for irrigation in 2008 and 2009, respectively.

The saving of water resulting from recycling was small compared with other studies, because the controls were given very little excess water. A study of tomato grown in coir without recycling applied $737 \mathrm{~mm}$ of nutrient solution and drained $219 \mathrm{~mm}(30 \%)$ over the season (Rincon et al., 2005). A study using perlite applied 630 and $225 \mathrm{~mm}$ in open and closed systems for a saving of 64\% (Dasgan and Ekici, 2005). Another study of open and closed systems using rockwool found recycling saved $36 \%$ to $44 \%$ of the water applied compared with the control (Komosa et al., 2011).

In each year, we observed a rapid rise in $\mathrm{EC}$ of the drainage solutions that occurred at or shortly after the plants began production of ripe fruit. Early in the season during vegetative growth, the nutrient solution was supplied with a high concentration of nutrients, $\mathrm{EC}=3 \mathrm{dS} \cdot \mathrm{m}^{-1}$. The concentration of the fresh solution was decreased to moderate the high EC. This also corresponded to the time when the ratio of nitrate to potassium was adjusted, decreasing nitrate and increasing potassium going from the vegetative to reproductive phase. A more dilute fresh solution, $\mathrm{EC}=$ $1.7 \mathrm{dS} \cdot \mathrm{m}^{-1}$, soon lowered the EC of the control solution (Fig. 1). The nutrient solution continued to be supplied at a lower concentration for the rest of the season. Thereafter, the EC of the solution drained from the control system remained relatively low, 2 to $4 \mathrm{dS} \cdot \mathrm{m}^{-1}$, whereas EC rose to 5 to $6 \mathrm{dS} \cdot \mathrm{m}^{-1}$ in the solution drained from the recycled system. Similar target ECs were used by Hao and 
Papadopoulos (2002) when recycling nutrient solution to greenhouse tomato grown in rockwool. However, they decreased the EC gradually from 2.5 to $1.8 \mathrm{dS} \cdot \mathrm{m}^{-1}$ over fruit production and achieved the target EC by diluting the recycled solution. In 2008, the EC was always higher in solution drained from the recycled system compared with controls. In 2009, the EC was higher in the controls until after the first correction of the
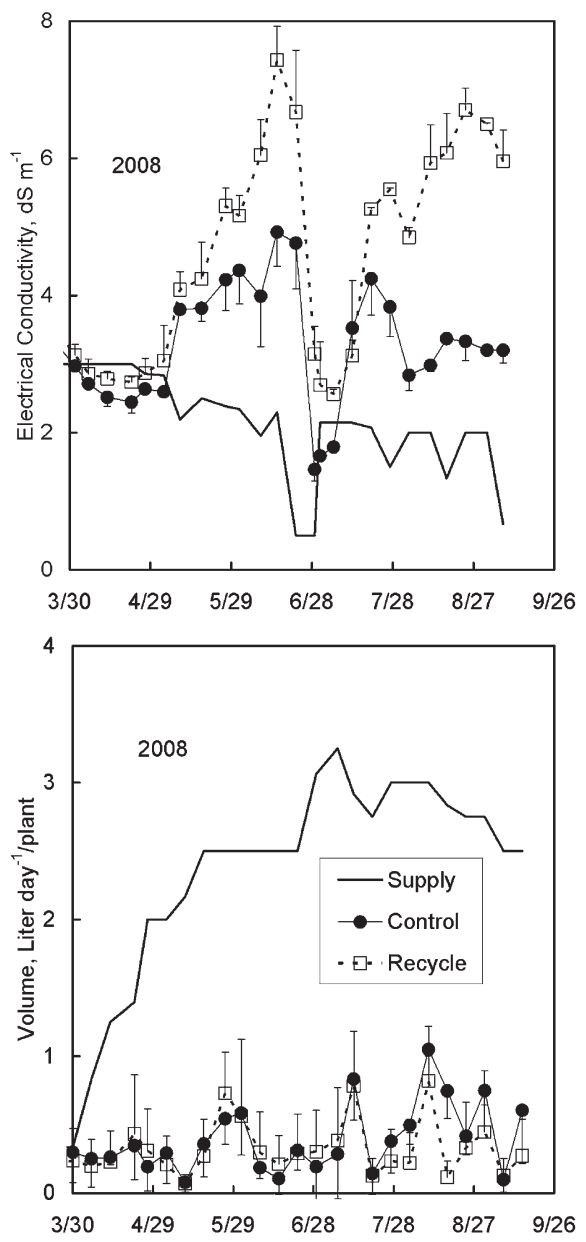

Fig. 1. The volume and electrical conductivity (EC) of water supplied to the two watering systems (Supply) and the water drained from control (Control) and recycled (Recycle) systems. The volume of fresh solution is reported for the control system, and EC in the fresh solution was the same for recycled and control systems. The error bars indicate the range in measurements from replicate systems in two greenhouses.
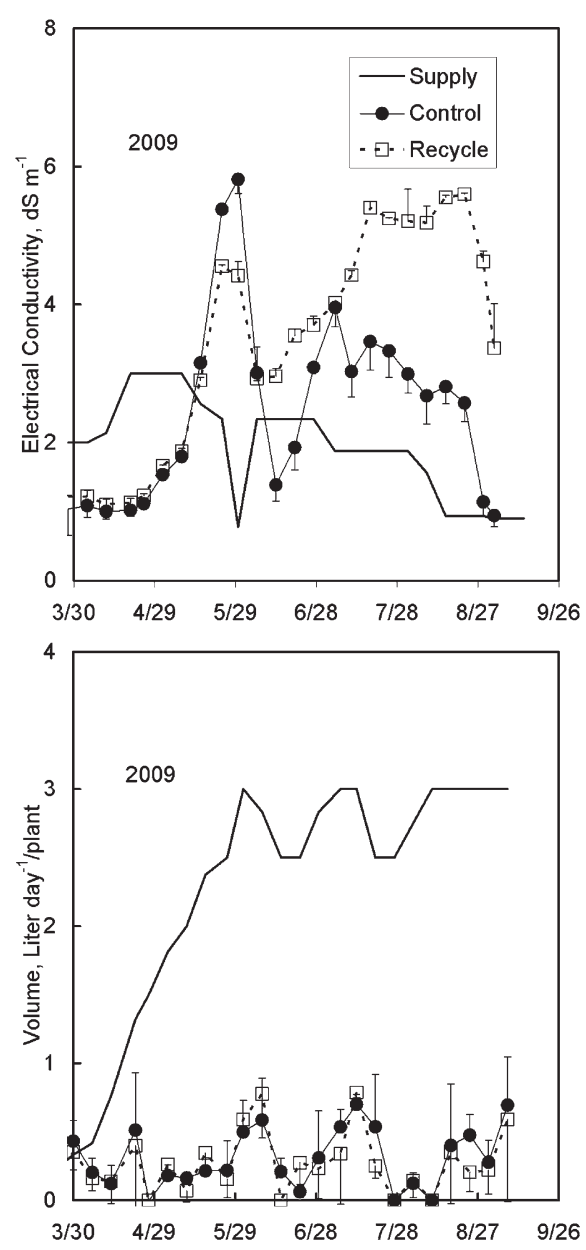

nutrient solutions. This difference between years was likely the result of slight differences in the ratio of volume of water supplied compared with plant uptake.

$\mathrm{EC}$ is proportional to the sum of nutrients in the solution. Table 1 gives more information on the concentration of individual elements in these solutions for two times in each year, namely at the low point after adjustment of the nutrient solution in June or early July and then toward the end of the season when the recycled solution had a higher EC than the control. Most elemental concentrations were higher in the recycled than in the control system. This was especially obvious for potassium, sodium, and nitrate late in the season. Calcium did not differ. The minor nutrients differed relatively little between the two systems except for copper, which tended to be more than 2 -fold higher in the recycled system than in the control.

The loss of nutrient elements in the control system was calculated from the volume of solution drained times the concentration of nutrients in the drained solution. The amounts of macronutrients supplied were 25 and $22 \mathrm{~g}$ nitrogen $(\mathrm{N}), 20$ and $18 \mathrm{~g}$ phosphorus $(\mathrm{P})$, and 45 and $40 \mathrm{~g}$ potassium $(\mathrm{K})$ per plant in 2008 and 2009, respectively. The loss from the control system was 4.2 and $4.6 \mathrm{~g} \mathrm{~N}$, 2.4 and $2.3 \mathrm{~g} \mathrm{P}$, and 8 and $5 \mathrm{~g} \mathrm{~K}$ per plant in 2008 and 2009, respectively. As a fraction of the total supplied, these losses correspond to $17 \%$ and $21 \%$ for $\mathrm{N}, 12 \%$ and $13 \%$ for $\mathrm{P}$, and $18 \%$ and $12 \%$ for $\mathrm{K}$ in 2008 and 2009 , respectively.

An increase in EC is usually observed in recycling systems. For tomato grown in perlite, EC increased to 3 and $4.8 \mathrm{dS} \cdot \mathrm{m}^{-1}$ in open and closed systems, respectively (Dasgan and Ekici, 2005). They found a greater accumulation of $\mathrm{P}$, iron $(\mathrm{Fe})$, and manganese (Mn) with recycling over the course of the season. One study in rockwool found higher concentrations of nitrate, calcium $(\mathrm{Ca})$, and zinc in recycled compared with control solutions, but lower concentrations of $\mathrm{K}, \mathrm{Fe}, \mathrm{Mn}$, and copper (Komosa et al., 2011). Another study in rockwool found higher concentrations of nitrate, $\mathrm{Ca}$, and magnesium but lower concentrations of $\mathrm{K}$ and $\mathrm{P}$ in recycled solutions when $\mathrm{EC}$ was adjusted by dilution (Hao and Papadopoulos, 2002). Sulfate was another nutrient found to accumulate as a result of recycling (Zekki et al., 1996). The differences among these studies, and the present work, are likely the result of differences in the formulation of the fertilizers and the ratios of nutrients supplied to the plants. A comparison of recycling in rockwool and coir found nutrient concentrations more stable in coir, particularly if no $\mathrm{NH}_{4}-\mathrm{N}$ was supplied (Iwasaki and Saigusa, 2001). Commonly,

Table 1. Concentration of elements in the nutrient solution drained from plants in control or recycled systems and in the fresh solution supplied to the plants.

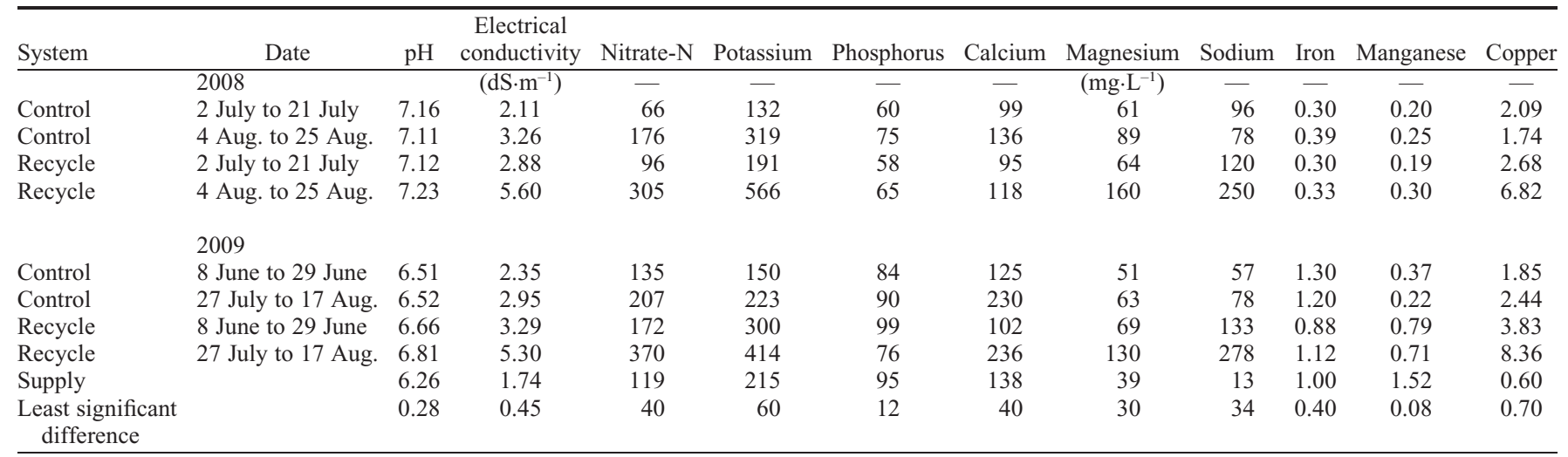


there is an accumulation of sodium $(\mathrm{Na})$ and chlorine (Dasgan and Ekici, 2005; Komosa et al., 2011; Lopez et al., 2003), because $\mathrm{Na}$ is preferentially excluded from the plant (Carmassi et al., 2005).

The savings of nutrients resulting from recycling with rockwool medium varied between $31 \%$ for $\mathrm{P}$ to $63 \%$ for $\mathrm{Ca}$ (Komosa et al., 2011), and in a study of four other media, the savings of nutrients resulting from recycling were calculated to be as high as $34 \%$ (Tuzel et al., 2001). These values are higher than reported here, because our controls were supplied with a much smaller

Fruit composition. In each year, the fruits from one harvest of tomato were subsampled to determine dry matter fraction and elemental concentration. There was no difference resulting from the treatments in dry matter, although there were differences between cultivars. 'Rapsodie' had the lowest dry matter fraction, $58 \mathrm{~g} \cdot \mathrm{kg}^{-1}$ fresh weight (FW), and 'Buffalo' and 'Geronimo' had the highest fraction, $67 \mathrm{~g} \cdot \mathrm{kg}^{-1} \mathrm{FW}$. When the elemental concentrations were deterexcess of solution.

mined on a FW basis, the cultivars did not differ, but there were differences resulting from recycling. The fruit from plants grown with recycling had a lower concentration of most elements. These elements included P, 15.6 vs. $14.6 \mathrm{mg} \cdot \mathrm{kg}^{-1} \mathrm{FW}$; Ca, 4.9 vs. $4.3 \mathrm{mg} \cdot \mathrm{kg}^{-1} \mathrm{FW}$; Fe, 0.75 vs. $0.64 \mathrm{mg} \cdot \mathrm{kg}^{-1}$ $\mathrm{FW}$; and $\mathrm{Mn}, 0.66$ vs. $0.52 \mathrm{mg} \cdot \mathrm{kg}^{-1} \mathrm{FW}$ in fruit from the control and recycle treatments, respectively, differences significant at $P<0.05$. Two exceptions were the concentrations of $\mathrm{K}$ and $\mathrm{Na}$. Potassium was $87 \mathrm{vs} .91 \mathrm{mg} \cdot \mathrm{kg}^{-1} \mathrm{FW}$, and $\mathrm{Na}$ was $0.5 \mathrm{vs} .0 .9 \mathrm{mg} \cdot \mathrm{kg}^{-1} \mathrm{FW}$ in fruit from the control and recycle treatments, respectively. Although $\mathrm{Na}$ was a small fraction of total cation content of the fruit, it showed the greatest relative change resulting from recycling.

In a study of tomato produced using coir, recycling increased dry matter content but lowered the concentration of mineral elements (Kobryn, 2002). Recycling in rockwool resulted in less $\mathrm{P}, \mathrm{K}$, and Mn but more $\mathrm{Ca}$ in fruit tissue (Komosa et al., 2011). We found all nutrients except $\mathrm{K}$ were lowered in fruit tissue by recycling. Others found no effect of recycling on composition of fruit. In

Table 2. Yield and fruit size of tomato cultivars grown in coir with control or recycled nutrient solution averaged over two years.

\begin{tabular}{|c|c|c|c|c|c|}
\hline Factor & $\frac{\text { Total yield }}{\text { (kg/plant) }}$ & $\frac{\text { Market yield }}{(\mathrm{kg} / \text { plant })}$ & $\frac{\text { Total size }}{(\mathrm{g})}$ & $\frac{\text { Market size }}{(\mathrm{g})}$ & Market fraction \\
\hline \multicolumn{6}{|l|}{$\overline{\mathrm{Yr}}$} \\
\hline 2008 & 9.5 & 5.5 & 179 & 182 & 0.573 \\
\hline 2009 & 7.5 & 3.8 & 184 & 187 & 0.505 \\
\hline Significance & 0.0001 & 0.0001 & 0.24 & 0.31 & 0.003 \\
\hline \multicolumn{6}{|l|}{ Treatment } \\
\hline Control & 8.9 & 4.7 & 187 & 189 & 0.517 \\
\hline Recycle & 8.1 & 4.6 & 176 & 179 & 0.561 \\
\hline Significance & 0.001 & 0.84 & 0.005 & 0.009 & 0.002 \\
\hline \multicolumn{6}{|l|}{ Cultivar } \\
\hline Arabason & $7.9 b^{z}$ & $4.6 \mathrm{~b}$ & $143 \mathrm{c}$ & $159 \mathrm{c}$ & $0.587 \mathrm{~b}$ \\
\hline Blitz & $8.4 \mathrm{ab}$ & $3.6 \mathrm{c}$ & $188 \mathrm{a}$ & $186 \mathrm{~b}$ & $0.434 \mathrm{c}$ \\
\hline Buffalo & $8.2 \mathrm{ab}$ & $4.5 \mathrm{bc}$ & $178 \mathrm{~b}$ & $172 \mathrm{c}$ & $0.546 \mathrm{~b}$ \\
\hline Cobra & $8.6 \mathrm{ab}$ & $4.3 \mathrm{bc}$ & $172 \mathrm{~b}$ & $172 \mathrm{c}$ & $0.493 \mathrm{c}$ \\
\hline Geronimo & $9.1 \mathrm{a}$ & $6.1 \mathrm{a}$ & $198 \mathrm{a}$ & $205 \mathrm{a}$ & $0.672 \mathrm{a}$ \\
\hline Rapsodie & $9.1 \mathrm{a}$ & $4.9 \mathrm{~b}$ & $201 \mathrm{a}$ & $208 \mathrm{a}$ & $0.530 \mathrm{~b}$ \\
\hline Trust & $8.4 \mathrm{ab}$ & $4.4 \mathrm{bc}$ & $192 \mathrm{a}$ & $189 \mathrm{~b}$ & $0.512 \mathrm{bc}$ \\
\hline Significance & 0.04 & 0.0002 & 0.0001 & 0.0001 & 0.0001 \\
\hline
\end{tabular}

${ }^{\mathrm{z}}$ Differences in values between cultivars followed by different letters are significant at $P<0.05$.

Table 3. Fraction of fruit with defects from tomato cultivars grown in coir with control or recycled nutrient solution averaged over two years.

\begin{tabular}{|c|c|c|c|c|c|c|}
\hline Factor & $\begin{array}{l}\text { Cracked } \\
\text { skin }\end{array}$ & $\begin{array}{l}\text { Rough } \\
\text { skin }\end{array}$ & $\begin{array}{c}\text { Green } \\
\text { shoulder }\end{array}$ & Small $(<50 \mathrm{~g})$ & $\begin{array}{c}\text { Blossom-end } \\
\text { rot }\end{array}$ & $\begin{array}{c}\text { Irregular } \\
\text { shape }\end{array}$ \\
\hline \multicolumn{7}{|l|}{$\mathrm{Yr}$} \\
\hline 2008 & 0.286 & 0.065 & 0.038 & 0.063 & 0.012 & 0.032 \\
\hline 2009 & 0.238 & 0.075 & 0.083 & 0.063 & 0.015 & 0.074 \\
\hline Significance & 0.003 & 0.12 & 0.0001 & 0.47 & 0.31 & 0.0001 \\
\hline \multicolumn{7}{|l|}{ Treatment } \\
\hline Control & 0.284 & 0.072 & 0.059 & 0.065 & 0.015 & 0.054 \\
\hline Recycle & 0.240 & 0.068 & 0.063 & 0.061 & 0.012 & 0.052 \\
\hline Significance & 0.002 & 0.60 & 0.61 & 0.67 & 0.38 & 0.83 \\
\hline \multicolumn{7}{|l|}{ Cultivar } \\
\hline Arabason & $0.256 b^{z}$ & $0.049 \mathrm{c}$ & $0.078 \mathrm{~b}$ & $0.124 \mathrm{a}$ & $0.008 \mathrm{~b}$ & $0.017 \mathrm{c}$ \\
\hline Blitz & $0.353 \mathrm{a}$ & $0.071 \mathrm{~b}$ & $0.078 \mathrm{~b}$ & $0.057 \mathrm{~b}$ & $0.010 \mathrm{~b}$ & $0.073 \mathrm{a}$ \\
\hline Buffalo & $0.296 \mathrm{~b}$ & $0.063 \mathrm{bc}$ & $0.010 \mathrm{c}$ & $0.041 \mathrm{~b}$ & $0.011 \mathrm{~b}$ & $0.054 \mathrm{~b}$ \\
\hline Cobra & $0.226 \mathrm{c}$ & $0.043 \mathrm{c}$ & $0.172 \mathrm{a}$ & $0.068 \mathrm{~b}$ & $0.008 \mathrm{~b}$ & $0.059 \mathrm{ab}$ \\
\hline Geronimo & $0.110 \mathrm{~d}$ & $0.101 \mathrm{a}$ & $0.034 \mathrm{c}$ & $0.040 \mathrm{~b}$ & $0.028 \mathrm{a}$ & $0.051 \mathrm{~b}$ \\
\hline Rapsodie & $0.288 \mathrm{~b}$ & $0.098 \mathrm{a}$ & $0.015 \mathrm{c}$ & $0.061 \mathrm{~b}$ & $0.012 \mathrm{~b}$ & $0.059 \mathrm{ab}$ \\
\hline Trust & $0.306 \mathrm{ab}$ & $0.065 \mathrm{bc}$ & $0.038 \mathrm{c}$ & $0.049 \mathrm{~b}$ & $0.016 \mathrm{~b}$ & $0.058 \mathrm{ab}$ \\
\hline Significance & 0.0001 & 0.0001 & 0.0001 & 0.0001 & 0.01 & 0.0001 \\
\hline
\end{tabular}

${ }^{\mathrm{z}}$ Differences in values between cultivars followed by different letters are significant at $P<0.05$. a previous study of recycling in rockwool, we found recycling increased $\mathrm{K}$ and $\mathrm{Na}$ in fruit tissue and decreased $\mathrm{P}$ and $\mathrm{Ca}$ in one of two cultivars (Gent and Short, 2012). When either $\mathrm{N}$ or $\mathrm{K}$ were supplied in excess to tomato grown in rockwool, there was no change in tomato fruit composition and little effect on yield (Gent, 2004a, 2004b). However, an increase in solution EC may decrease fruit size (Chretien et al., 2000) and increase dry matter content, although this is not always the case (Charbonneau et al., 1988). In our study EC was higher with recycling, and fruit size was decreased by recycling but in another study using recycled solution in which $\mathrm{EC}$ was adjusted by dilution (Hao and Papadopoulos, 2002), fruit size was unaffected.

Fruit yield and quality. The watering system affected total yield but not market yield (Table 2). There was a greater yield from the control than from the recycled systems, and the weight per fruit was greater for the control. However, the marketable percentage was greater in the recycled treatment. There were significant effects of year on total and market yield. There was greater yield in 2008 than 2009. The only significant interaction between treatment and year was in the marketable percentage. There was a greater marketable percentage in 2008 than 2009 , and the difference between treatments was greater than 2009 and 2008. The marketable fractions were 0.53 and 0.55 in 2008 , compared with 0.45 and 0.52 in 2009 , for control and recycle treatments, respectively. Cracked skin was the only fruit defect that differed significantly between treatments (Table 3). More fruit had cracked skin in the control compared with the recycle treatment. There were significant differences between years in the fraction with cracked skin, green shoulder, and irregular shape. Whereas there was a greater fraction of fruit with cracked skin in 2008, there were greater fractions of fruit with uneven ripening and irregular shape in 2009. A higher than usual incidence of cracked skin was observed in these trials in unshaded hoophouses. This style of greenhouse has poorer ventilation and temperature control than Venlo or openroof houses. The result is a high incidence of cracked skin unless the houses are shaded (Gent, 2007).

There were significant differences between cultivars in all yield characteristics (Table 2). 'Geronimo' and 'Rapsodie' had the highest total yield and 'Arabason' had the lowest yield. 'Geronimo' had the highest market yield by a large margin and 'Blitz' had the lowest marketable yield. 'Geronimo' and 'Rapsodie' had the largest fruit and 'Arabason' had the smallest. 'Geronimo' had the greatest fraction of marketable fruit by a large margin and 'Blitz' had the smallest marketable fraction among those cultivars grown for two years. 'Blitz' had the greatest fraction with cracked skin, and 'Geronimo' had the least. 'Geronimo' and 'Rapsodie' had the largest faction of rough fruit, and 'Arabason' had the smallest. This seemed to be related to fruit size. 'Cobra' had the greatest fraction 
of green shoulder and 'Arabason' and 'Blitz' had intermediate amounts. The other cultivars were uniform ripening. 'Arabason' had many more small fruit than any other cultivar. No cultivar had more than $3 \%$ of fruit with blossom-end rot. 'Arabason' had the least number of irregular fruit and 'Blitz' had the most.

There were two interactions between effects of cultivar and treatment and year. For the green shoulder defect, the source of this interaction was primarily the result of the cultivars Arabason and Cobra. 'Arabason' had more green shoulder in the recycle treatment in 2008 and more in the discharge treatment in 2009. 'Cobra' had far more fruit with green shoulder in 2009 than 2008, and the difference between treatments was much greater in 2008 than 2009. 'Geronimo' had a higher fraction of blossom-end rot in 2008 than in 2009, which was contrary to most cultivars. Except for these two instances, all cultivars responded similarly to the recycle or control watering systems.

Other studies of the effects of recycling have found only slight or inconsistent effects on yield. A study of open and closed (recycled) fertigation systems with various substrates (Tuzel et al., 2001) found no significant difference in total yield between the two systems in fall or in the spring, although there was a greater number of fruits in the recycled system. Studies using perlite resulted in greater yield for the control than the recycle treatment (Dasgan and Ekici, 2005). Yield did not differ as a result of recycling in studies that used rockwool (Komosa et al., 2011), even when $\mathrm{Na}$ accumulated in a recycling system (Isozaki et al., 2004). However, recycling in a nutrient film system did lower tomato yield and quality (Lopez et al., 2003). This was attributed to an accumulation of sulfate (Zekki et al., 1996). A study of recycling, which compared solutions with three ratios of nitrate to chloride and sulfate, found that marketable yield of tomatoes was only depressed by a solution with high concentrations of both chloride and sulfate (Nukaya and Hashimoto, 2000). This combination increased the incidence of blossom-end rot. We found that recycling had little effect on blossom-end rot, and the response was cultivar-specific.

Recycling often improves fruit quality, as noted in the present work. When recycled solution with high EC was fed to tomato grown on a capillary mat, fewer fruit had cracked skin than in controls without recycling (Okano et al., 2000). High EC generally lowers the incidence of cracked skin, but it can also reduce fruit size (Chretien et al., 2000). In our previous study of two cultivars of tomato grown in rockwool, the effects of recycling on yield were cultivar-specific (Gent and Short, 2012). Fewer fruit of 'Geronimo' and 'Quest' had cracked skin or green shoulder when grown with recycled solution, but recycled solution increased the fraction of marketable fruit only for 'Quest'.

In the simple recycling system examined here, in which untreated solution was recycled to the plants through a second manifold, the principal drawback was a slow response to adjustment of the fresh solution. Nutrient concentrations in the fresh solution supplied to the plants were adjusted when an oversupply of nitrate and other nutrients occurred during the transition from vegetative to fruit growth. However, the EC of the solutions drained from the recycle system responded more slowly than for the control to this adjustment. The EC rose again to a high value in the recycled system. Total yield was reduced but marketable yield was similar in the recycled compared with the control system. Although yield components and frequency of fruit defects differed among the seven cultivars studied here, in general, they had similar responses to recycling.

\section{Literature Cited}

Anonymous. 1989. National environmental policy plan. Ministry of Housing, Planning and the Environment, The Hague, The Netherlands [in Dutch].

Carmassi, G., L. Incrocci, R. Maggini, F. Malorgio, F. Tognoni, and A. Pardossi. 2005. Modeling salinity buildup in recirculating nutrient solution culture. J. Plant Nutr. 28:431-445.

Charbonneau, J., A. Gosselin, and M.J. Trudel. 1988. Effect of electrical conductivity of the nutrient solution on growth and development of greenhouse tomato cultivated with or without supplementary lighting. Can. J. Plant Sci. 68:267-276 [in French].

Chretien, S., A. Gosselin, and M. Dorais. 2000. High electrical conductivity and radiation based water management improve fruit quality of greenhouse tomatoes grown in rockwool. HortScience 35:627-631.

Dasgan, H.Y. and B. Ekici. 2005. Comparison of open and recycling systems for ion accumulation of substrate, nutrient uptake and water and water use of tomato plants. Acta Hort. 697: 399-408.

Gent, M.P.N. 2004a. Effect of nitrogen and potassium supply on yield and tissue composition of greenhouse tomato. Acta Hort. 644: 369-375.

Gent, M.P.N. 2004b. Yield of greenhouse tomato in response to supplemental nitrogen and potassium. Acta Hort. 633:341-348.

Gent, M.P.N. 2007. Effect of degree and duration of shade on quality of greenhouse tomato. HortScience 42:514-520.

Gent, M.P.N. and M.R. Short. 2012. Managing a simple system to recycle nutrient solution to greenhouse tomato grown in rockwool. Acta Hort. 927:913-919.

Grattan, S.R. and C.M. Grieve. 1999. Salinity and mineral nutrient relationships in horticultural crops. Sci. Hort. 78:127-157.

Hao, X. and A.P. Papadopoulos. 2002. Growth, photosynthesis, and productivity of greenhouse tomato cultivated in open or closed rockwool systems. Can. J. Plant Sci. 82:771-780.

Ho, L.C., P. Adams, X.Z. Li, H. Shen, J. Andrews, and Z.H. Xu. 1995. Responses of Ca efficient and $\mathrm{Ca}$ inefficient tomato cultivars to salinity in plant growth $\mathrm{Ca}$ accumulation and blossom end rot. J. Hort. Sci. Biotechnol. 70:909-918.

Isozaki, M., N. Konishi, M. Kuroki, Y. Nomura, and K. Tanaka. 2004. Growth of tomato plants and changes in nutrient element concentrations in the rockwool system with a device to recycle used nutrient solutions. J. Japan. Soc. Hortic. Sci. 73:354-363.
Iwasaki, Y. and M. Saigusa. 2001. Effects of NO3/ $\mathrm{NH} 4$ ratios of nutrient solution on the fluctuation of ion concentration of a recirculating nutrient solution and the growth and yields of tomato in closed hydroponic system using coir as a substrate. Japan. J. Soil Sci. Plant Nutr. 72:214-222 [in Japanese with English abstract].

Jensen, M.H., P.A. Rorabaugh, and A. Garcia. 2004. Comparing five growing media for physical characteristics and tomato yield potential. 20 Oct. 2012. <http://ag.arizona.edu/ceac/sites/ ag.arizona.edu.ceac/files/Comparing\%20Media $\% 201998 \% 2099 \% 20 w P i c t u r e . p d f>$.

Kobryn, J. 2002. Effect of substrate type on the yield and quality of tomato fruits (Lysopersicon esculentum Mill) in glasshouse cultivation. Folia Hort. 14:53-59.

Komosa, A., J. Pirog, Z. Weber, and B. Markiewicz. 2011. Comparison of yield, nutrient solution changes and nutritional status of greenhouse tomato grown in recirculating and non-recirculating nutrient solution systems. J. Plant Nutr. 34: 1473-1488.

Lopez, J., J. Santos-Perez, and S. Lozano-Trejo. 2003. Mineral nutrition and productivity of hydroponically grown tomatoes in relation to nutrient recycling. Acta Hort. 609:219-223.

Mazuela, P., M. Urrestarazu, M.C. Salas, C. Guillen, and J.A. Sanchez. 2004. Comparison between different fertigation parameters and yield using pure compost and coir waste fibre in tomato (Lycopersicon esculentum cv Pitenza) crop by soilless culture. Acta Hort. 659:653-656.

Norrie, J., M.E.D. Graham, and A. Gosselin. 1994. Potential evapotranspiration as a means of predicting irrigation timing in greenhouse tomatoes grown in peat bags. J. Amer. Soc. Hort. Sci. 119:163-168.

Nukaya, A. and H. Hashimoto. 2000. Effects of nitrate chloride and sulfate ratios and concentration in the nutrient solution on yield growth and mineral uptake characteristics of tomato plants grown in closed rockwool system. Acta Hort. 511:165-171.

Okano, K., Y. Sakamoto, and S. Watanabe. 2000. Reuse of drainage water for the production of high quality fruits in single-truss tomato grown in a closed hydroponic system. Acta Hort. 511:277-286.

Resh, H.M. 1991. Hydroponic food production. Woodbridge Press, Santa Barbara, CA

Rincon, L., A. Perez, A. Abadia, and C. Pellicer. 2005. Yield, water use and nutrient uptake of a tomato crop grown on coconut coir dust. Acta Hort. 697:73-79.

Roorda van Eysinga, J.P.N.L. and K.W. Smilde. 1981. Nutritional disorders in glasshouse tomatoes, cucumbers and lettuce. Centre for Agric. Pub. and Documentation, Wageningen, The Netherlands.

Tuzel, I.H., Y. Tuzel, A. Gul, M.K. Merik, O. Yavuz, and R.Z. Eltez. 2001. Comparison of open and closed systems on yield and nutrient consumption and their environmental impact. Acta Hort. 554:221-228.

van Os, E.A., T.H. Gieling, and J.H. Lieth. 2008 Technical equipment in soilless production systems. In: Ravis, M. and J.H. Lieth (eds.). Soilless culture: Theory and practice. Elsevier.

Wittwer, S.H. and S. Honma. 1979. Greenhouse tomatoes, lettuce and cucumber. Michigan State University Press, East Lansing, MI.

Zekki, H., L. Gauthier, and A. Gosselin. 1996. Growth productivity and mineral composition of hydroponically cultivated greenhouse tomatoes with or without nutrient solution recycling. J. Amer. Soc. Hort. Sci. 121:1082-1088. 